\title{
IMPROVEMENT OF CARBON DIOXIDE CAPTURE USING GRAPHITE WASTE/ $\mathrm{Fe}_{3} \mathrm{O}_{4} \mathrm{COMPOSITES}$
}

\author{
Eny Kusrini ${ }^{*}$, Angga Kurniawan Sasongko ${ }^{1}$, Nasruddin ${ }^{2}$, Anwar Usman ${ }^{3}$ \\ ${ }^{1}$ Department of Chemical Engineering, Faculty of Engineering, Universitas Indonesia, \\ Kampus UI Depok, Depok 16424, Indonesia \\ ${ }^{2}$ Department of Mechanical Engineering, Faculty of Engineering, Universitas Indonesia, \\ Kampus UI Depok, Depok 16424, Indonesia \\ ${ }^{3}$ Department of Chemistry, Faculty of Science, Universiti Brunei Darussalam, Jalan Tungku Link, \\ Gadong BE1410, Negara Brunei Darussalam
}

(Received: July 2017 / Revised: August 2017 / Accepted: October 2017)

\begin{abstract}
The abundance of graphite waste can be processed into valuable materials; one alternative is by making it into an adsorbent. Graphite-based adsorbent modification can be accomplished by adding magnetite nanoparticles $\mathrm{Fe}_{3} \mathrm{O}_{4}$. The addition of magnetite nanoparticles has been reported to improve the adsorption ability of the graphite waste. In this study, we have developed a new carbon dioxide $\left(\mathrm{CO}_{2}\right)$ adsorbent based on graphite waste modified with magnetite nanoparticle $\mathrm{Fe}_{3} \mathrm{O}_{4}$. The $\mathrm{Fe}_{3} \mathrm{O}_{4}$ were prepared using an impregnation technique. The graphite $/ \mathrm{Fe}_{3} \mathrm{O}_{4}$ composites were characterized by scanning electron microscopy with an energydispersive X-ray system (SEM-EDX) and Brunauer, Emmett, and Teller (BET). The $\mathrm{CO}_{2}$ adsorption performance was evaluated using an isothermal adsorption method at various temperatures $\left(30,35\right.$, and $\left.45^{\circ} \mathrm{C}\right)$ and pressures $(3,5,8,15$, and 20 bar). This resulted in graphite with different magnetite modification levels, namely non-modified graphite (GNM), a graphite $/ \mathrm{Fe}_{3} \mathrm{O}_{4} 20 \%$ (w/w) composite $\left(\mathrm{G} / \mathrm{Fe}_{3} \mathrm{O}_{4} 20 \%\right.$ ), and a graphite/ $/ \mathrm{Fe}_{3} \mathrm{O}_{4} \quad 35 \%$ (w/w) $\left(\mathrm{G} / \mathrm{Fe}_{3} \mathrm{O}_{4} 35 \%\right)$, which indicated that the largest adsorption capacity is $10.305 \mathrm{mmol} . \mathrm{g}^{-1}$ at $30^{\circ} \mathrm{C}$ and 20 bar pressure for the $\mathrm{G} / \mathrm{Fe}_{3} \mathrm{O}_{4} 20 \%$ composite. This finding further revealed that modifying graphite waste with magnetite nanoparticles $\mathrm{Fe}_{3} \mathrm{O}_{4}$ has been proved to increase the capacity for adsorbing $\mathrm{CO}_{2}$ gas.
\end{abstract}

Keywords: Adsorption; Carbon dioxide capture; Graphite/ $\mathrm{Fe}_{3} \mathrm{O}_{4}$ composites; Graphite waste; Isotherm adsorption; Magnetite nanoparticle $\mathrm{Fe}_{3} \mathrm{O}_{4}$

\section{INTRODUCTION}

Global warming and climate change have now pushed the whole world to reduce the concentration of atmospheric carbon dioxide $\left(\mathrm{CO}_{2}\right)$ gas (Tiwari et al., 2017). As much as 50 to $80 \%$ of the total $\mathrm{CO}_{2}$ gas emissions have been targeted by intergovernmental panels on climate change to reduce the massive consequences of global warming. Various technologies have been created to reduce $\mathrm{CO}_{2}$ emissions, such as adsorption using solids, absorption with liquid, membrane technology, and cryogenic distillation (Vilarrasa-García et al., 2017; Shin et al., 2016)

Among the aforementioned technologies, adsorption is the favorite and the most efficient

\footnotetext{
*Corresponding author's email: eny.k@ui.ac.id, Tel: +62-21-786-3516 ext. 204, Fax: +62-21-786-3515
} Permalink/DOI: https://doi.org/10.14716/ijtech.v8i8.697 
compared with other techniques (Lee \& Park, 2015; Mishra \& Ramaprabhu, 2014). Adsorption method using solid sorbents shows many advantages in overcome with $\mathrm{CO}_{2}$ post-combustion capture (Lee \& Park, 2015). $\mathrm{CO}_{2}$ post-combustion capture used wet or dry sorbents, that it can be used for separation of gas, such as for separate and storage $\mathrm{CO}_{2}$ using adsorption/desorption (Lee \& Park, 2015). Some porous media, such as activated carbons, graphite, zeolite-modified $\mathrm{MgO}$, graphitic carbon nitride nanosheets, graphite oxide (GO), graphitic nanostructure, and graphene, have been used as a sorbent for $\mathrm{CO}_{2}$ (Rashidia et al., 2016; Mishra \& Ramaprabhu, 2011(a); Shin et al., 2016; Casco et al., 2014; Ghosh \& Ramaprabhu 2017; Zukal et al., 2017; Babu et al., 2017). $\mathrm{CO}_{2}$ capture using porous solids has become an advanced technology used to reduce $\mathrm{CO}_{2}$ emissions (Casco et al., 2014). Activated carbons show a high adsorption capacity (Vences-Alvarez et al., 2015), an easy regeneration, and a high selectivity for $\mathrm{CO}_{2}$ capture with respect to other compounds, such as methane and nitrogen (Casco et al., 2017).

However, the adsorbents on the market are sometimes expensive and ineffective; therefore, it is necessary to find other types of adsorbent for easy and cheap application in the manufacturing process. Graphite waste can be sourced from the processing in the aluminum industry, particularly in the electrolysis process. The number of industries that use this electrolysis method results in much graphite waste, which can be categorized as a dangerous and poisonous material. However, it could be developed into a new valuable product for use as a sorbent (Pasca, 2016). However, the graphite waste also has a weakness such as quite narrow pore size distribution and un-uniform. They are also difficult to recover after use. Therefore to considered to be suitable as sorbent for $\mathrm{CO}_{2}$ capture, the surface modification and pore size control are needed. In order to increase the surface area of the graphite waste and increase the recovery of the sorbents, we have to modify the graphite waste with magnetite nanoparticles $\mathrm{Fe}_{3} \mathrm{O}_{4}$.

Magnetite nanoparticles $\mathrm{Fe}_{3} \mathrm{O}_{4}$ have a high surface area, as good adsorbent due to their colloidal stabilization (Mahmoud et al., 2017) and environmental remediation due to having a rapid adsorption rate, have a high adsorption capacity, have magnetic separation, and this material can be regenerated. Moreover, the addition of magnetite nanoparticles $\mathrm{Fe}_{3} \mathrm{O}_{4}$ makes the graphite become stable when it is used to adsorb gas, especially at high temperatures (Mishra \& Ramaprabhu, 2014).

In this study, we have developed new $\mathrm{CO}_{2}$ adsorbents based on graphite waste modified with magnetite nanoparticles $\mathrm{Fe}_{3} \mathrm{O}_{4}$. The graphite waste was prepared using a temperature of $60^{\circ} \mathrm{C}$

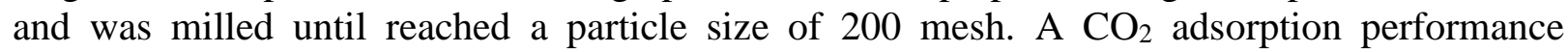
isotherm evaluation was conducted at various temperatures $\left(30,35\right.$, and $\left.45^{\circ} \mathrm{C}\right)$ and pressures $(3$, $5,8,15$, and 20 bar). The volumetric adsorption measurement technique was used. This method was commonly used and has the advantage of simplicity of design and cost effectiveness (Elsayed et al., 2017).

\section{METHODS}

\subsection{Preparation of Magnetite Nanoparticles $\mathrm{Fe}_{3} \mathrm{O}_{4}$ and $\mathrm{G}_{3} \mathrm{Fe}_{3} \mathrm{O}_{4}$ Composites}

The $\mathrm{G} / \mathrm{Fe}_{3} \mathrm{O}_{4}$ sorbent was prepared in three steps. The first step was preparing the graphite waste by using a heat pre-treatment at $60^{\circ} \mathrm{C}$ for 3 hours. The pre-treatment was continued by reducing the graphite to powdered particles using a ball mill, which was followed by sieving through a sieve with a filter size of 200 mesh (Pasca, 2016).

In the second step, the magnetite nanoparticles $\mathrm{Fe}_{3} \mathrm{O}_{4}$ were synthesized using a co-precipitation method. The synthesis began with mixing two main precursors, which are $\mathrm{FeCl}_{3} .6 \mathrm{H}_{2} \mathrm{O}$ and $\mathrm{FeCl}_{2} .4 \mathrm{H}_{2} \mathrm{O}$ (Merck, USA), with a 3:1 mass ratio with a $1 \mathrm{~N} \mathrm{HCl}$ solvent. The mixture was blended and stirred using a magnetic stirrer until all the soluble and colored material became clear. Further dilution was conducted by adding $15 \mathrm{~mL}$ of water de-mineralization, it was 
stirred and kept for 15 minutes, then poured into $250 \mathrm{~mL}$ of ammonium hydroxide $1.5 \mathrm{M}$, so that it formed a black precipitate and could respond to an external magnetic field. The stirred solution was taken out in 1 hour using a closed container to prevent the $\mathrm{Fe}_{3} \mathrm{O}_{4}$ becoming oxidized. To obtain dry magnetite nanoparticles $\mathrm{Fe}_{3} \mathrm{O}_{4}$, the precipitate was washed with aquadest until the $\mathrm{pH}$ was 7 . The final step was putting the slurry form of the magnetite nanoparticles $\mathrm{Fe}_{3} \mathrm{O}_{4}$ into an oven at a temperature of $60^{\circ} \mathrm{C}$.

The last step to prepare the $\mathrm{G} / \mathrm{Fe}_{3} \mathrm{O}_{4}$ composite was combining the graphite that has been pretreated with $\mathrm{Fe}_{3} \mathrm{O}_{4}$ using an impregnation method. In this study, two variations for the addition of magnetite nanoparticles $\mathrm{Fe}_{3} \mathrm{O}_{4}$ were completed, which are $20 \%(\mathrm{w} / \mathrm{w})$ and $35 \%$ $(\mathrm{w} / \mathrm{w})$. The process began with the use of as much as $6.4 \mathrm{~g}$ of graphite, while for the $\mathrm{Fe}_{3} \mathrm{O}_{4} 1.6 \mathrm{~g}$ was used for the $\mathrm{G} / \mathrm{Fe}_{3} \mathrm{O}_{4} 20 \%$ composite whereas $5.2 \mathrm{~g}$ and $2.8 \mathrm{~g}$ were used for the $\mathrm{G} / \mathrm{Fe}_{3} \mathrm{O}_{4}$ $35 \%$ composite. Then, the two materials were dissolved into $100 \mathrm{~mL}$ of water as a solvent and it was stirred for 4 hours, which was intended to make sure the magnetite nanoparticles $\mathrm{Fe}_{3} \mathrm{O}_{4}$ and graphite were mixed completely and that the bond cannot easily be separated. The process was continued by washing the precipitate with aquadest until $\mathrm{pH}$ reached neutral, at 7 , and this was followed by drying it in an oven for 2 hours at $60^{\circ} \mathrm{C}$.

\subsection{Characterization}

The morphology and elemental composition of graphite non-modification (GNM) and $\mathrm{G} / \mathrm{Fe}_{3} \mathrm{O}_{4}$ composites were characterized using scanning electron microscopy (SEM) with an energydispersive X-ray system (EDX). The specific surface area, pore volume, particle size, and Barrett-Joyner-Halenda (BJH) surface area of the adsorbents were measured at a liquid nitrogen temperature of $77 \mathrm{~K}$ using a Brunauer, Emmett, and Teller (BET) analyzer (model ASAP 2020 V4.02 (V4.02 E), Micromeritics, US) with analysis adsorptive $\mathrm{N}_{2}$, an equilibration interval of 5 seconds, and no low-pressure dose. Prior to the BET analysis, the sample was subjected to degassing under high vacuum at $350^{\circ} \mathrm{C}$ for 4 hours.

\subsection{Determination of Adsorption Capacity}

The adsorption capacities of $\mathrm{CO}_{2}$ using $\mathrm{GNM}$ and $\mathrm{G} / \mathrm{Fe}_{3} \mathrm{O}_{4}$ sorbents were determined using the adsorption isotherm by volumetric principle. The experiment's setup consisted of two stainless tubes, namely a charging cell $(\mathrm{Cc})$ and measuring cell $(\mathrm{Mc})$; a circulating water bath from HÜBER as the control to keep the water temperature constant; elbow joints; needle valves; a pressure transmitter with a pressure range of 0-40 bar procured from DRUCK PTX 1400; and a thermocouple type $\mathrm{K}$ class $\mathrm{A}$ that was used to measure the temperature inside the measuring cell and charging cell.

The basis of volumetric measurement is the pressure, volume, and temperature at which data is measured when the adsorbate enters the area where the adsorbent is located. After equilibrium is reached, the amount of $\mathrm{CO}_{2}$ adsorbed is calculated from the pressure changes that occur by using the ideal gas equation.

The adsorption experiments were performed in the pressure range of 3-20 bar at 30, 35, and $45^{\circ} \mathrm{C}$, and each cycle of the adsorption experiment was followed by $\mathrm{CO}_{2}$ degassing at $150^{\circ} \mathrm{C}$ under vacuum conditions. This process helps to remove any impurities from the adsorbent (Awaluddin, 2010).

\section{RESULTS AND DISCUSSION}

\subsection{Characterization of Adsorbents}

The surface area, pore volume, and particle size of the adsorbents is shown in Table 1. The magnetite nanoparticles $\mathrm{Fe}_{3} \mathrm{O}_{4}$ were prepared using an impregnation technique. The BET surface area of the $\mathrm{Fe}_{3} \mathrm{O}_{4}$ is $120.20 \mathrm{~m}^{2} / \mathrm{g}$. As the magnetite nanoparticles $\mathrm{Fe}_{3} \mathrm{O}_{4}$ were 
impregnated and distributed in surface of the graphite waste, and had pores, the surface area of the $\mathrm{G} / \mathrm{Fe}_{3} \mathrm{O}_{4} 20 \%$ and $35 \%$ composites increased after being modified with magnetite nanoparticles $\mathrm{Fe}_{3} \mathrm{O}_{4}$. The BET surface area of $\mathrm{G} / \mathrm{Fe}_{3} \mathrm{O}_{4} 20 \%$ and $35 \%$ composites are 18.48 and $35.52 \mathrm{~m}^{2} / \mathrm{g}$, respectively. We know that if the pore volume is larger than in its pristine condition, the adsorption capacity of $\mathrm{CO}_{2}$ is also greater (Babu et al., 2017). The BET surface area of GNM is very low and less than $10 \mathrm{~m}^{2} / \mathrm{g}$, indicated that the GNM is non-porous. For comparison purposes, the non-porous of glass platelets show no significant pores with an average BET surface area of $0.43 \mathrm{~m}^{2} / \mathrm{g}$ has been reported Schadeck et al. (2017).

Table 1 BET characterization of the adsorbents

\begin{tabular}{lrccr}
\hline \multicolumn{1}{c}{ Parameters } & $\mathrm{GNM}$ & $\mathrm{G} / \mathrm{Fe}_{3} \mathrm{O}_{4} 20 \%$ & $\mathrm{G} / \mathrm{Fe}_{3} \mathrm{O}_{4} 35 \%$ & $\mathrm{Fe}_{3} \mathrm{O}_{4}$ \\
\hline BET surface area $\left(\mathrm{m}^{2} / \mathrm{g}\right)$ & 8.49 & 18.48 & 35.52 & 120.20 \\
BJH surface area $\left(\mathrm{m}^{2} / \mathrm{g}\right)$ & 7.941 & 18.275 & 32.11 & 109.79 \\
BJH volume of pores $\left(\mathrm{cm}^{3} / \mathrm{g}\right)$ & 0.03 & 0.07 & 0.12 & 0.42 \\
Average particle size $(\mathrm{nm})$ & 706.45 & 324.63 & 168.93 & 49.52 \\
Pore diameter $(\mathrm{nm})$ & 16.37 & 14.39 & 14.42 & 15.26 \\
\hline
\end{tabular}

SEM is used to study the morphology of graphite and after modified with magnetite nanoparticles $\mathrm{Fe}_{3} \mathrm{O}_{4}$. All of the SEM imaging appeared as aggregates and roughness, flakes of large particles. No porous was observed. Figure 1(a) shows an SEM image of graphite after pretreated with thermal and mechanic. Figure 1(b) and (c) shows an SEM image of the graphite waste after modified with $\mathrm{Fe}_{3} \mathrm{O}_{4}$. Both SEM images showed, the entire magnetite nanoparticles $\mathrm{Fe}_{3} \mathrm{O}_{4}$ is well impregnated into surface and pore of graphite waste.
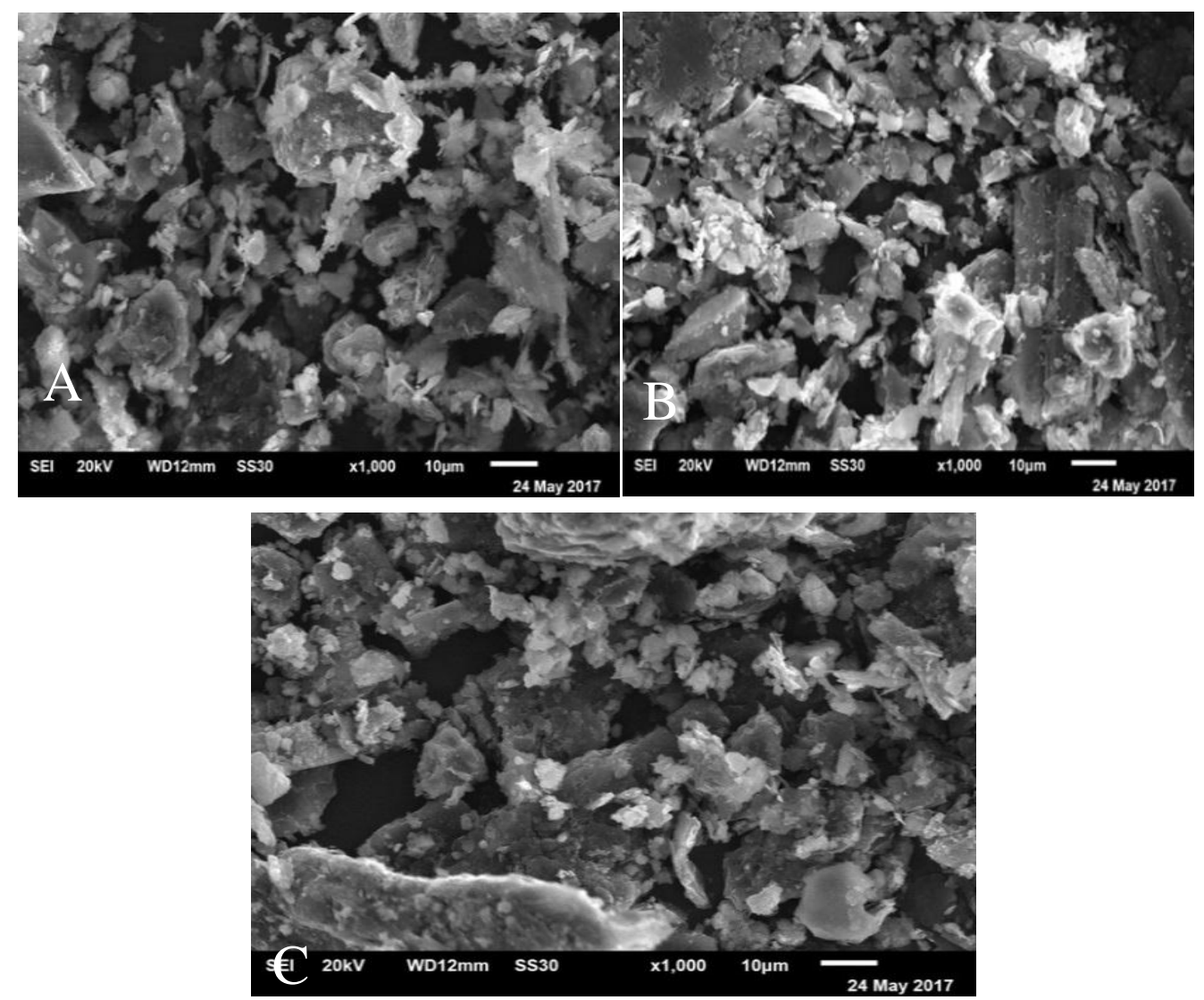

Figure 1 SEM Analysis of: (a) GNM; (b) $\mathrm{G} / \mathrm{Fe}_{3} \mathrm{O}_{4} 20 \%$ composite; and (c) $\mathrm{G} / \mathrm{Fe}_{3} \mathrm{O}_{4} 35 \%$ composite 
The elemental composition of three types of sorbents was listed in Table 2. The Fe content was observed in both $\mathrm{G} / \mathrm{Fe}_{3} \mathrm{O}_{4} 20 \%$ and $35 \%$ composites. Si in GNM was not observed in both composite sorbents. The $\mathrm{G} / \mathrm{Fe}_{3} \mathrm{O}_{4} 35 \%$ composite, Fe content is very little. We assumed that it is due to the preparation or saturated the surface of graphite.

Table 2 EDX composition of adsorbent

\begin{tabular}{cccc}
\hline Element & $\mathrm{GNM}$ & $\mathrm{G} / \mathrm{Fe}_{3} \mathrm{O}_{4} 20 \%$ & $\mathrm{G} / \mathrm{Fe}_{3} \mathrm{O}_{4} 35 \%$ \\
\hline $\mathrm{C}$ & 80.09 & 76.96 & 92.8 \\
$\mathrm{O}$ & 5.22 & 8.21 & - \\
$\mathrm{F}$ & 9.58 & 6.64 & 4.67 \\
$\mathrm{Na}$ & 3.35 & 1.31 & 1.07 \\
$\mathrm{Al}$ & 0.97 & 0.68 & 0.55 \\
$\mathrm{Si}$ & 0.19 & - & - \\
$\mathrm{Ca}$ & 0.60 & 0.37 & 0.43 \\
$\mathrm{Fe}$ & - & 5.82 & 0.46 \\
\hline
\end{tabular}

\section{2. $\quad \mathrm{CO}_{2}$ Adsorption Isotherms}

The amount of $\mathrm{CO}_{2}$ adsorbed was measured from the pressure changes that occurred by using the ideal gas equation. The mass balance of the adsorbate vapor in the charging cell and the measuring cell can be assumed as follows (Dawoud \& Aristov, 2003, Awaluddin, 2010):

$$
\boldsymbol{m}_{d_{j} m c}=\left|\boldsymbol{m}_{c c}\right|-\boldsymbol{m}_{a d s}
$$

where $m_{d, m e}$ is the mass of adsorbate in the measuring cell $(\mathrm{kg}) ; \mid m_{c o} l$ is the mass of adsorbate in the charging cell that migrated into the measuring cell $(\mathrm{kg}) ; m_{\text {ads }}$ is the mass of adsorbate that was adsorbed in the adsorbent $(\mathrm{kg})$. During the process of migrating from the charging cell to the measuring cell, the adsorbate had a compressibility factor value ( $\mathrm{Z}$ value) which transforms Equation 1 into the following:

$$
\begin{gathered}
\left|m_{c c}\right|=\Delta m_{c c}=m_{c c}(t)-m_{c c}(t+\Delta t)=\frac{\left(p_{c c}(t)-p_{c c}(t+\Delta t)\right) V_{c c}}{z R_{c c} T_{c c}} \\
m_{d, m e}=m_{d, m e}(t+\Delta t)-m_{d, m e}(t)=\frac{\left(p_{m c}(t+\Delta t)-p_{m c}(t)\right) V_{c c}}{z R_{m c} T_{m e}}
\end{gathered}
$$

By substituting Equations 2 and 3 into Equation 1, then we get the following:

$$
\begin{gathered}
m_{a d s}=\Delta m_{a d s}(t) \\
m_{a d s}=\frac{\left(p_{c c}(t)-p_{c c}(t+\Delta t)\right) V_{c c}}{z R_{c c} T_{c c}}-\frac{\left(p_{m e}(t+\Delta t)-p_{m e}(t)\right) V_{c c}}{z R_{m e} T_{m e}}
\end{gathered}
$$

Or

$$
m_{a d s}=\rho_{c c}(P, T) V_{c c}-\rho_{m e}(P, T) V_{m e}
$$

All composites are used for $\mathrm{CO}_{2}$ adsorption at various temperatures ranging from 30 to $45^{\circ} \mathrm{C}$, and pressures in the range from 3 to 20 bar. Figures $2(\mathrm{a}-\mathrm{c})$ demonstrate the $\mathrm{CO}_{2}$ adsorption isotherms of GNM, G/Fe $\mathrm{O}_{4} 20 \%$ composite, and $\mathrm{G} / \mathrm{Fe}_{3} \mathrm{O}_{4} 35 \%$ composite at temperatures of 30,35 , and $45^{\circ} \mathrm{C}$ and pressures from 3 to 20 bar. It is clearly disclosing that the $\mathrm{CO}_{2}$ capture 
capacity increases with pressure at each temperature. It is similar observed with $\mathrm{CO}_{2}$ capture using $\mathrm{Fe}_{3} \mathrm{O}_{4}$-graphene nanocomposite by physicochemical adsorption, as reported by Mishra and Ramaprabhu (2014). This increase in capture capacity with pressure may be attributed to the flow rate of the gas pounding on the surface of the graphite waste, which becomes larger as the pressure increases and allows the amount of adsorbate attached to the graphite surface to also get larger (Awaluddin, 2010).

The adsorption behavior of the $\mathrm{GNM}, \mathrm{G} / \mathrm{Fe}_{3} \mathrm{O}_{4} 20 \%$, and $\mathrm{G} / \mathrm{Fe}_{3} \mathrm{O}_{4} 35 \%$ at three different temperatures are presented in Figures $2(\mathrm{a}-\mathrm{c})$. A maximum adsorption capacity of 10.305 mmol.g ${ }^{1}$ was found for the $\mathrm{G} / \mathrm{Fe}_{3} \mathrm{O}_{4} 20 \%$ composite, $7.907 \mathrm{mmol} . \mathrm{g}^{-1}$ for $\mathrm{G} / \mathrm{Fe}_{3} \mathrm{O}_{4} 35 \%$ composite, and $6.437 \mathrm{mmol.g}{ }^{-1}$ for GNM, at 20 bar and $30^{\circ} \mathrm{C}$ (see Figures 2(a-c)). At 20 bar and $35^{\circ} \mathrm{C}$, the maximum adsorption capacities were $8.182 \mathrm{mmol} . \mathrm{g}^{-1}, 6.863 \mathrm{mmol} . \mathrm{g}^{-1}$, and 5.597 mmol.g ${ }^{-1}$ for $\mathrm{G} / \mathrm{Fe}_{3} \mathrm{O}_{4} 20 \%, \mathrm{G} / \mathrm{Fe}_{3} \mathrm{O}_{4} 35 \%$, and $\mathrm{GNM}$, respectively. At 20 bar and $45^{\circ} \mathrm{C}$, the maximum adsorption capacities were $5.331 \mathrm{mmol.g} \mathrm{g}^{-1}, 5.323 \mathrm{mmol.g} \mathrm{g}^{-1}$, and $4.756 \mathrm{mmol.g} \mathrm{g}^{-1}$ for $\mathrm{G} / \mathrm{Fe}_{3} \mathrm{O}_{4} 20 \%, \mathrm{G} / \mathrm{Fe}_{3} \mathrm{O}_{4} 35 \%$, and $\mathrm{GNM}$, respectively.
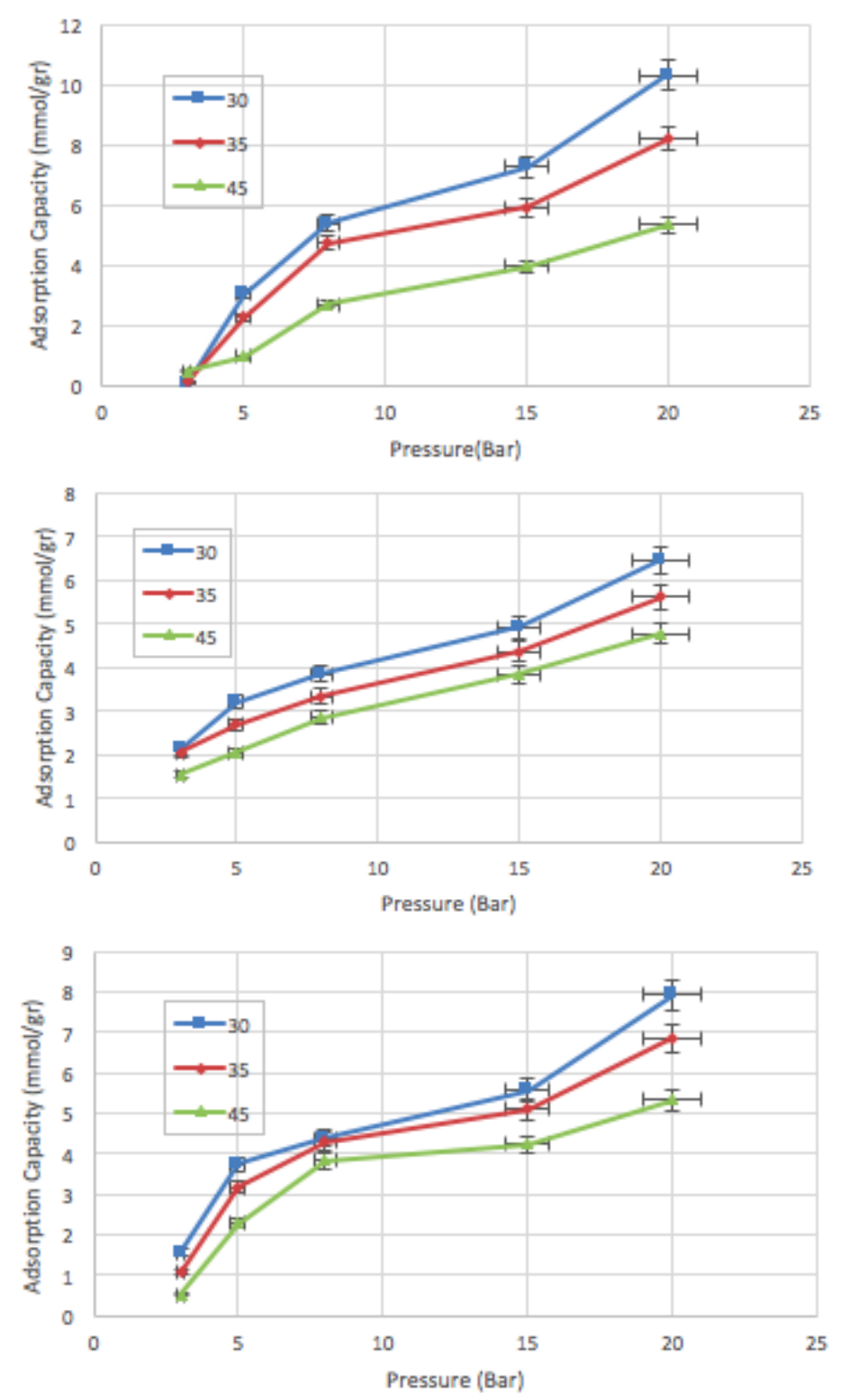

(c)

Figure 2 Adsorption capacity of $\mathrm{CO}_{2}$ versus the pressure of $\mathrm{CO}_{2}$ for: (a) GNM; (b) $\mathrm{G} / \mathrm{Fe}_{3} \mathrm{O}_{4} 20 \%$ composite; and (c) $\mathrm{G} / \mathrm{Fe}_{3} \mathrm{O}_{4} 35 \%$ composite 
The modified graphite with magnetite nanoparticles $\mathrm{Fe}_{3} \mathrm{O}_{4}$ is better at adsorbing $\mathrm{CO}_{2}$ gas when compared with non-modified graphite. The increased amount of $\mathrm{CO}_{2}$ adsorption capacity for graphite modified with $\mathrm{Fe}_{3} \mathrm{O}_{4}$ compared to non-modified graphite is due to the fact that physical adsorption is not the only mechanism in the adsorption of $\mathrm{CO}_{2}$, but chemical adsorption is also involved, which causes the adsorption capacity for $\mathrm{CO}_{2}$ gas to become larger (Mishra \& Ramaprabhu, 2014). The physisorption is associated with the surface area and the pores of the adsorbent, whereas the chemisorption is related to the bonding of $\mathrm{CO}_{2}$ gas molecules with magnetite nanoparticles $\mathrm{Fe}_{3} \mathrm{O}_{4}$ (Mishra \& Ramaprabhu, 2011a). The $\mathrm{CO}_{2}$ adsorption is physisorption, where the adsorption capacity increases with the $\mathrm{CO}_{2}$ pressure but it decreases with temperature.

Furthermore, the addition of the magnetite nanoparticles $\mathrm{Fe}_{3} \mathrm{O}_{4} 35 \%$ does not make the adsorption capacity bigger when compared with the addition of $\mathrm{Fe}_{3} \mathrm{O}_{4} 20 \%$. This is due to the iron content in $\mathrm{G} / \mathrm{Fe}_{3} \mathrm{O}_{4} 35 \%$ composite not being as much as in the $\mathrm{G} / \mathrm{Fe}_{3} \mathrm{O}_{4} 20 \%$ composite (see Table 2) due to aggregation among the molecules of the magnetite nanoparticles $\mathrm{Fe}_{3} \mathrm{O}_{4}$, which leads to the formation of an agglomeration. This phenomenon also makes the binding to the $\mathrm{CO}_{2}$ molecule less than from the addition of magnetite nanoparticles $\mathrm{Fe}_{3} \mathrm{O}_{4}(20 \%(\mathrm{w} / \mathrm{w}))$.

The effect of temperatures on the adsorption capacity of $\mathrm{CO}_{2}$ gas can also be seen in Figure 3. It can be observed that the lower the temperature, the greater the adsorption capacity. This occurred because the higher temperatures make the $\mathrm{CO}_{2}$ gas molecules move faster due to their kinetic energy being increased. This phenomenon causes the interaction between the $\mathrm{CO}_{2}$ molecules and the $\mathrm{G} / \mathrm{Fe}_{3} \mathrm{O}_{4}$ composite in porous surfaces to become lower, which results in a lower $\mathrm{CO}_{2}$ adsorption (Mishra \& Ramaprabhu, 2011b).

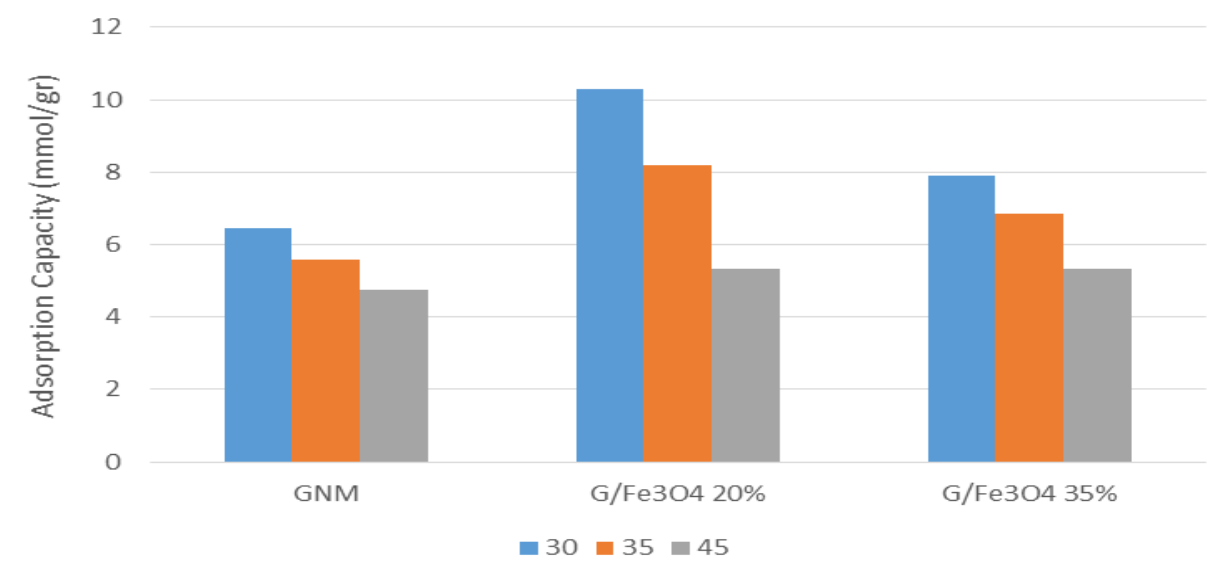

Figure 3 The effect of the type of adsorbent on adsorption capacity

\subsection{Comparison of Capacity Adsorption of $\mathrm{CO}_{2}$ with Other Adsorbents}

The best $\mathrm{CO}_{2}$ adsorption in the present work is using a $\mathrm{G} / \mathrm{Fe}_{3} \mathrm{O}_{4} 20 \%$ composite, which has a high adsorption capacity of $5.36 \mathrm{mmol} . \mathrm{g}^{-1}$ at 8 bar pressure, but at a maximum pressure of 20 bar, the adsorption capacity of $10.306 \mathrm{mmol} . \mathrm{g}^{-1}$. Mishra and Ramaprabhu (2011b) report that with graphite material nanoplatelets $/ \mathrm{Fe}_{3} \mathrm{O}_{4}$ a capacity of nearly $8.5 \mathrm{mmol} . \mathrm{g}^{-1}$ was acquired at 11 bar pressure and room temperature. A comparison of the $\mathrm{CO}_{2}$ adsorption for the graphite waste used in this study with other types of adsorbents is summarized in Table 3.

Although the adsorption capacity of $\mathrm{CO}_{2}$ using $\mathrm{G} / \mathrm{Fe}_{3} \mathrm{O}_{4}$ composites in this study is lower than the other adsorbents mentioned in Table 3, but the graphite waste has potential to compete with other supporting materials and/or other adsorbents. For further study, modifying graphite using magnetite nanoparticles $\mathrm{Fe}_{3} \mathrm{O}_{4}$ has the potential to be used as an industrial-scale adsorbent, whereas other adsorbents, such as activated carbon and zeolites, have limited adsorption only at 
room temperature and continue to decrease their capacity as operating temperatures increase (Mishra \& Ramaprabhu, 2011b).

Table 3 Comparison of the adsorption capacity of $\mathrm{CO}_{2}$ with other adsorbents

\begin{tabular}{llcc}
\hline \multicolumn{1}{c}{ Authors } & \multicolumn{1}{c}{ Adsorbent } & $\begin{array}{c}\text { Adsorption capacity } \\
\left(\text { mmol.g }{ }^{-1}\right)\end{array}$ & Operating condition \\
\hline $\begin{array}{l}\text { Present work, } \\
2017\end{array}$ & $\begin{array}{l}\text { Graphite } / \mathrm{Fe}_{3} \mathrm{O}_{4} 20 \% \\
\text { composite }\end{array}$ & 5.36 & $30^{\circ} \mathrm{C}, 8 \mathrm{bar}$ \\
\hline $\begin{array}{l}\text { Mishra \& } \\
\text { Ramaprabhu, }\end{array}$ & $\begin{array}{l}\text { Graphite } \\
\text { Nanoplatelets } / \mathrm{Fe}_{3} \mathrm{O}_{4}\end{array}$ & 8.5 & $25^{\circ} \mathrm{C}, 11 \mathrm{bar}$ \\
$\begin{array}{l}\text { Mishra \& } \\
\text { Ramaprabhu, } \\
2014\end{array}$ & $\begin{array}{l}\mathrm{Fe}_{3} \mathrm{O}_{4}-\text { Graphene } \\
\text { nanocomposite }\end{array}$ & 60 & $25^{\circ} \mathrm{C}, 11 \mathrm{bar}$ \\
\hline
\end{tabular}

\section{CONCLUSION}

We have developed and tested graphite waste $/ \mathrm{Fe}_{3} \mathrm{O}_{4}\left(\mathrm{G} / \mathrm{Fe}_{3} \mathrm{O}_{4}\right)$ composites as an adsorbent for the adsorption of $\mathrm{CO}_{2}$. The best condition for adsorbing $\mathrm{CO}_{2}$ gas was using a $\mathrm{G} / \mathrm{Fe}_{3} \mathrm{O}_{4} 20 \%$ composite at $30^{\circ} \mathrm{C}$ and a pressure of 20 bar, which had an adsorption capacity of 10.305 mmol.g ${ }^{-1}$. The addition of magnetite nanoparticles $\mathrm{Fe}_{3} \mathrm{O}_{4}$ produced an adsorption capacity of $\mathrm{CO}_{2}$ that is higher compared with non-modified graphite (GNM).

\section{ACKNOWLEDGEMENT}

The authors greatly acknowledge the Universitas Indonesia for providing financial support through a grant, Hibah PITTA No. 774/UN2.R3.1/HKP.05.00/2017.

\section{REFERENCES}

Awaluddin, M., 2010. Carbon dioxide and Methane Isotherm Adsorption on Activated Carbon Based on Coal Sub-Biuminus's Indonesia for Purification and Storage Natural Gas. Universitas Indonesia.

Babu, C., Vinodh, R., Selvamani, A., Kumar, K., Parveen, A., Thirukumaran, P., Ramkumar, V., 2017. Organic Functionalized $\mathrm{Fe}_{3} \mathrm{O}_{4} / \mathrm{RGO}$ Nanocomposites for $\mathrm{CO}_{2}$ Adsorption. Journal of Environmental Chemical Engineering, Volume 5(3), pp. 2440-2447

Casco, M.E., Aaro’n Morelos-Go’mez, Vega-Dı'az, S.M., Cruz-Silva, R., Trista'n-López, F., Muramatsu, H., Hayashi, T., Martı'nez-Escandell, M., Terrones, M., Endo, M., Rodri'guezReinoso, F., Silvestre-Albero, J., 2014. $\mathrm{CO}_{2}$ Adsorption on Crystalline Graphitic Nanostructures. Journal of $\mathrm{CO}_{2}$ Utilization, Volume 5, pp. 60-65

Dawoud, B., Aristov, Y., 2003. Experimental Study on the Kinetics of Water Vapor Sorption on Selective Water Sorbent, Silica Gel and Alumina under Typical Operating Conditions of Sorption Heat Pumps. International Journal of Heat and Mass Transfer, Volume 46(2), pp. 273-281

Elsayed, A.M., Askalany, A.A., Shea, A.D., Dakkama, H.J., Mahmoud, S., Al-Dadah, R., Kaialy, W., 2017. A State of the Art of Required Techniques for Employing Activated Carbon in Renewable Energy Powered Adsorption Applications. Renewable and Sustainable Energy Reviews, Volume 79, pp. 503-519

Ghosh, S., Ramaprabhu, S., 2017. High-pressure Investigation of Ionic Functionalized Graphitic Carbon Nitride Nanostructures for $\mathrm{CO}_{2}$ Capture. Journal of $\mathrm{CO}_{2}$ Utilization, Volume 21, pp. 89-99 
Lee, S-Y., Park, S-J., 2015. A Review on Solid Adsorbents for Carbon Dioxide Capture. Journal of Industrial and Engineering Chemistry, Volume 23, pp. 1-11

Mahmoud, M.E., Khalifa, M.A.,. El Wakeel, Y.M., Header, M.S., Abdel-Fattah, T.M., 2017. Engineered Nano-magnetic Iron Oxide-urea-activated Carbon Nanolayer Sorbent for Potential Removal of Uranium (VI) from Aqueous Solution. Journal of Nuclear Materials, Volume 487, pp. 13-22

Mishra, A.K., Ramaprabhu, S., 2011a. Nano Magnetite Decorated Multiwalled Carbon Nanotubes: a Robust Nanomaterial for Enhanced Carbon Dioxide Adsorption. Energy and Environemtal Sciences, Volume 4(3), pp. 889-895

Mishra, A.K., Ramaprabhu, S., 2011b. Magnetite Decorated Graphite Nanoplatelets as Cost Effective $\mathrm{CO}_{2}$ Adsorbent. Journal of Materials Chemistry, Volume 21(20), pp. 7467-7471

Mishra, A.K., Ramaprabhu, S., 2014. Enhanced $\mathrm{CO}_{2}$ Capture in $\mathrm{Fe}_{3} \mathrm{O}_{4}$-graphene Nanocomposite by Physicochemical Adsorption. Journal of Applied Physics, Volume 116(6), pp. 064306-1 - 064306-5.

Pasca, G., 2016. Modification of Graphite using Magnetite Nanoparticles as Adsorbent for Dye's Textil Waste. Universitas Indonesia, Depok, Indonesia

Rashidi, N.A., Yusup, S., Borhan. A., 2016. Isotherm and Thermodynamic Analysis of Carbon Dioxide on Activated Carbon. Procedia Engineering, Volume 148, pp. 630-637

Shin, G.-J., Rhee, K.Y., Park, S.-J., 2016. Improvement of $\mathrm{CO}_{2}$ Capture by Graphite Oxide in Presence of Polyethylenimine. International Journal of Hydrogen Energy, Volume 41(32), pp. 14351-14359

Szczęśniak, B., Choma, J., Jaroniec, M., 2017. Gas adsorption properties of graphene-based materials, Advances in Colloid and Interface Science, Volume 243, pp. 46-59.

Schadeck, U., Kyrgyzbaeva, K., Gerdesa, T., Willert-Porada, M., Moos, R., 2017. Porous and non-porous micrometer-sized glass platelets as separators for lithium-ion batteries, Journal of Membrane Science, In Press.

Tiwari, D., Goel, C., Bhunia, H., Bajpai. P.K., 2017. Dynamic $\mathrm{CO}_{2}$ Capture by Carbon Adsorbents: Kinetics, Isotherm and Thermodynamic Studies. Separation and Purification Technology, Volume 181, pp. 107-122

Vences-Alvarez, E., Velazquez-Jimenez, L.H., Chazaro-Ruiz, L.F., Diaz-Flores, P.E., RangelMendez, J.R., 2015. Fluoride Removal in Water by a Hybrid Adsorbent Lanthanumcarbon. Journal of Colloid and Interface Science, Volume 455, pp. 194-202

Vilarrasa-García, E., Cecilia, J.A., Azevedo, D.C.S., Cavalcante Jr., C.L., Rodríguez-Castellon, E., 2017. Evaluation of Porous Clay Heterostructures Modified with Amine Species as Adsorbent for the $\mathrm{CO}_{2}$ Capture. Microporous and Mesoporous Materials, Volume 249, pp. $25-33$

Zukal, A., Kubů, M., Pastva. J., 2017. Two-dimensional Zeolites: Adsorption of Carbon Dioxide on Pristine Materials and on Materials Modified by Magnesium Oxide. Journal of $\mathrm{CO}_{2}$ Utilization, Volume 21, pp. 9-16 